\title{
Motivasi Belajar Mahasiswa: Peran Dukungan Sosial Melalui Mediator
} Religiositas

\author{
Raden Rachmy Diana ${ }^{1 *}$, Adam Anshori ${ }^{2}$, Sumedi P. Nugraha ${ }^{3}$, Yoga Achmad Ramadhan, ${ }^{4}$ \\ Lukman $^{5}$ \\ UIN Sunan Kalijaga Yogyakarta, Universitas Islam Indonesia Yogyakarta, Universitas 17 \\ Agustus 1945 Samarinda \\ 11raden.diana@uin-suka.ac.id, ${ }^{2}$ alexanderanshori@gmail.com, ${ }^{3}$ sumedi.nugraha@uii.ac.id, \\ ${ }^{4}$ yogachmadr@gmail.com, ${ }^{5}$ lukman.ahmadirfan@uii.ac.id \\ *Correspondence
}

\section{Article Information:}

Received 28 May 2021

Revised 29 August 2021

Accepted 04 September 2021

Keywords:

Learning motivation; Social support; Religiosity;

University Students

Kata Kunci:

Dukungan sosial; mahasiswa; motivasi belajar; Religiositas

\section{Abstract}

Students' motivation to learn has many important influences on university students. Motivation can increase learning involvement, learning autonomy, social presence and enrolment, critical thinking skills, writing skills, problem-solving skills, and learning achievement. This study aims to determine the effect of social support on student learning motivation through the mediator of religiosity. The research subjects were 202 students (male and female) at an Islamic university. The measuring instruments used are the Islamic Religiosity Scale from Nashori, the Multidimensional Scale of Perceived Social Support from Zimet, Dahlem, Zimet, and Farley, and the Learning Motivation Scale from Utami, Nashori, and Rachmawati. The data were analyzed using stepwise regression. The results showed that social support and religiosity influenced learning motivation. So, social support influenced learning motivation with religiosity as a full mediator.

Abstrak
Motivasi belajar mahasiswa memberi berbagai pengaruh penting terhadap diri mahasiswa. Motivasi dapat meningkatkan keterlibatan belajar, kemandirian belajar, penerimaan dan kehadiran sosial, kemampuan berpikir kritis, kemampuan menulis, kemampuan pemecahan masalah, dan prestasi belajar. Penelitian ini bermaksud mengetahui pengaruh dukungan sosial terhadap motivasi belajar mahasiswa melalui mediator religiositas. Subjek penelitian adalah 202 mahasiswa (laki-laki dan perempuan), pada sebuah universitas Islam. Alat ukur yang digunakan adalah Skala Religiositas Islam dari Nashori, the Multidimensional Scale of Perceived Social Support dari Zimet, Dahlem, Zimet, dan Farley, dan Skala Motivasi Belajar dari Utami, Nashori, dan Rachmawati. Data dianalisis dengan menggunakan regresi bertahap. Hasil penelitian menunjukkan bahwa (a) dukungan sosial memberikan pengaruh terhadap religiusitas, (b) religiusitas memberi pengaruh terhadap motivasi belajar, (c) dukungan sosial tidak berpengaruh terhadap motivasi belajar, dan (d) dukungan sosial memberikan pengaruh terhadap 
motivasi belajar dengan religiositas sebagai mediator yang sempurna.

\section{PENDAHULUAN}

Motivasi belajar merupakan faktor pokok untuk mengantarkan mahasiswa mengalami perkembangan pribadi. Motivasi belajar berperan meningkatkan prestasi akademik (Wiyoko \& Setiawan, 2019), keterlibatan dalam belajar (Dunn \& Kennedy, 2019), kemampuan belajar mandiri (Oh, 2017), dan niat perilaku belajar (Sun \& Gao, 2020) mahasiswa. Selain itu, motivasi belajar juga dapat meningkatkan penerimaan dan kehadiran sosial (Law, Geng, \& Li, 2019), tingkat kedisiplinan (Mustafidah, 2010), kemampuan belajar (Permana, 2016), keterampilan menulis berita (Akidah \& Mansyur, 2019), kemampuan berpikir kritis (Zanthy, 2016), perilaku belajar (Manurung, 2017), kemampuan berpikir kritis matematis (Anita, 2015), kemampuan pemecahan masalah (Sappaile \& Pristiwaluyo, 2019), dan hasil belajar (Rasdjo, Hendrayana, Erisyani, \& Setiana, 2016) mahasiswa. Motivasi belajar juga menurunkan kecemasan mahasiswa dalam pembelajaran bahasa asing (Utami \& Nurjati, 2017) dan menurunkan kecemasan mahasiswa dalam mengikuti ujian (Novitarum, Tampubolon, \& Manurung, 2018).

Motivasi belajar, sebagaimana disampaikan McCown, Driscoll, dan Roop (1996), adalah suatu disposisi yang dimiliki oleh subjek didik, yang ditandai oleh kesediaan mereka untuk memulai aktivitas belajar, kemudian dilanjutkan dengan keterlibatan mereka dalam suatu tugas pelajaran, serta komitmen belajar. McCown dkk. menjelaskan beberapa aspek dari motivasi belajar, yaitu adanya keinginan bersungguh-sungguh belajar, adanya keterlibatan siswa-siswa untuk mengerjakan tugas yang diberikan, dan adanya komitmen untuk terus belajar.

Dalam proses pembelajaran, motivasi belajar yang rendah ditandai oleh kesukaan membolos, menunda bahkan lalai mengerjakan tugas, tidak menyiapkan ujian secara baik, keengganan menyelesaikan bagian yang harus dikerjakan dalam tugas kelompok. Sebuah wawancara dengan seorang dosen (N, laki-laki, 50 tahun) menunjukkan banyak mahasiswa yang mengerjakan tugas dengan kualitas yang rendah, mengandalkan kemampuan teman sekelompoknya saat menyelesaikan tugas kelompok. Ketika dilakukan pengecekan oleh dosen tentang keterlibatan mahasiswa dalam tugas kelompok, banyak mahasiswa yang dilaporkan temannya terlibat sangat minimal dalam tugas kelompok, ada yang menyerahkan sepenuhnya kepada teman sekelompoknya, bahkan lepas tanggung jawab atas tugas kelompok. Di era pandemi, satu fenomena rendahnya motivasi belajar dapat dilihat dari keterlibatan mahasiswa untuk tidak memberi tanggapan atau menyampaikan pertanyaan melalui media daring atas penjelasan yang diberikan dosennya.

Hal penting yang perlu diidentifikasi adalah apa saja faktor penting yang mempengaruhi motivasi belajar mahasiswa. Dukungan sosial adalah faktor penting yang mempengaruhi motivasi belajar. Sarafino dan Smith (2012) mengartikan dukungan sosial sebagai kenyamanan, perhatian, penghargaan ataupun bantuan yang diterima individu 
dari orang lain maupun kelompok. Zimet, Dahlem, Zimet, dan Farley (1988) mengungkapkan ada tiga aspek dukungan sosial, yaitu dukungan keluarga, dukungan orang spesial, dan dukungan teman. Dukungan keluarga adalah dukungan yang berasal dari anggota keluarga, seperti ayah, ibu, dan saudara. Dukungan orang spesial adalah dukungan orang yang dianggap spesial, seperti kekasih, orang yang dikagumi, guru atau dosen. Dukungan teman adalah dukungan yang berasal dari teman seumuran atau teman seperjuangan. Hasil-hasil riset (Chen, 2015; Emeralda \& Kristiana, 2017; Mata, Monteiro, \& Peixoto, 2012; Suciana \& Rozali, 2014) menunjukkan bahwa dukungan sosial yang dirasakan dari keluarga, teman, orang-orang khusus yang diterima oleh mahasiswa dikaitkan dengan dan berkontribusi pada motivasi belajar. Secara lebih spesifik ditemukan bahwa dukungan sosial dari dosen (Filak \& Sheldon, 2008) dan dukungan sosial teman sebaya (Sakiz, 2012) terbukti dapat meningkatkan motivasi belajar mahasiswa.

Selain dukungan sosial, religiositas merupakan faktor yang secara empiris mempengaruhi motivasi belajar adalah religiositas. Ancok dan Suroso (2018) mengartikan religiositas sebagai tingkat pengetahuan, keyakinan, pelaksanaan, dan penghayatan seseorang atas ajaran agama yang diyakininya. Aspek-aspek religiositas meliputi akidah, ibadah, akhlak, ihsan, dan ilmu agama. Satu kesatuan aspek religiositas oleh Barus (2017) disebut sebagai tauhid yang menjadi landasan aktivitas muslim, dalam hal ini mahasiswa muslim, baik terkait bidang sosial, ekonomi, politik, maupun budaya. Dikatakan oleh Najati (2015) bahwa motivasi belajar yang kuat itu dapat muncul karena religiositas yang dimiliki individu. Ketika individu mengetahui isi ajaran agama Islam, maka individu tahu bahwa agama mendorong individu untuk memiliki kesungguhan dalam belajar. Hasil riset menunjukkan bahwa religiositas memberikan pengaruh terhadap motivasi belajar (Fatima, Mehfooz, \& Sharif, 2017; Rettinger \& Jordan, 2005) dan motivasi berprestasi (Susilawati, 2018; Syauqi, 2019) mahasiswa. Penelitian Barrett, Patock-Peckham, Hutchinson, dan Nagoshi (2005) juga menunjukkan bahwa orientasi religiositas berpengaruh secara signifikan terhadap motivasi kognitif mahasiswa di sebuah universitas. Selain itu, penelitian Trisno (2010) menemukan bahwa mahasiswa yang aktif dalam kegiatan kerohanian (aktivitas religiositas) memiliki motivasi berprestasi lebih tinggi daripada mahasiswa yang tidak aktif dalam kegiatan kerohanian. Kurnianingtyas (2015) juga menemukan bahwa religiositas berpengaruh secara signifikan terhadap motivasi belajar mahasiswa.

Dukungan sosial, sebagaimana dilaporkan berbagai riset, memberikan pengaruh terhadap religiositas. Religiositas tidak hanya bersumber dari sifat asal manusia yang mempercayai Allah sebagai Tuhannya (Ancok \& Suroso, 2018). Lebih dari itu adalah religiositas dibentuk oleh lingkungan di mana individu tumbuh dan berkembang. Lingkungan yang menciptakan situasi yang mendukung tumbuh kembangnya religiositas akan menjadikan individu menjadi pribadi yang religious (Jalaluddin, 2016). Hal ini didukung oleh hasil penelitian Paninten dan Indrawati (2020) yang menunjukkan bahwa 
dukungan sosial berpengaruh terhadap religiositas individu. Orangtua yang mengkondisikan anaknya untuk shalat lima lima waktu akan mengantarkan individu menjadi pribadi yang taat menegakkan shalat.

Berdasarkan penjelasan di atas, dapat disebutkan bahwa dukungan sosial memberikan pengaruh terhadap motivasi belajar secara langsung dan dapat juga melalui mediator dalam hal ini adalah religiusitas. Namun, sejauh ini belum ada riset yang secara empiris melibatkan tiga variabel dengan menempatkan religiusitas sebagai variabel moderator. Karenanya, menarik untuk dikaji secara empiris apakah religiositas memberikan pengaruh secara langsung atau menjadi perantara pengaruh dukungan sosial terhadap motivasi belajar mahasiswa. Kalau sebagai perantara, maka dukungan sosial yang tinggi akan diikuti oleh religiositas sehingga memunculkan motivasi belajar bagi mahasiswa. Peran religiositas sebagai mediator inilah yang menjadi sisi kebaruan dari riset ini, dikarenakan riset-riset sebelumnya hanya melihat pengaruh empiris religiositas terhadap motivasi belajar dan pengaruh dukungan sosial terhadap motivasi belajar. Dengan demikian, tujuan penelitian ini adalah mengetahui pengaruh dukungan sosial terhadap motivasi belajar mahasiswa melalui mediator religiositas. Hipotesis yang diajukan adalah (a) dukungan sosial memberi pengaruh terhadap religiusitas, (b) religiusitas memberi pengaruh terhadap motivasi belajar, (c) dukungan sosial memberi pengaruh terhadap motivasi belajar, dan (d) dukungan sosial memberi pengaruh terhadap motivasi belajar dengan religiositas sebagai mediator.

\section{METODOLOGI}

Subjek penelitian adalah 202 orang mahasiswa (laki-laki dan perempuan) yang beragama Islam, dan yang aktif sebagai mahasiswa sebuah universitas Islam di Yogyakarta, Indonesia. Mereka adalah mahasiswa beberapa program studi yang terkait dengan ilmu sosial dan humaniora.

Dalam penelitian ini digunakan tiga alat ukur, yaitu: (a) skala motivasi, (b) skala dukungan sosial, dan (c) skala religiositas. Skala motivasi belajar dimaksudkan untuk mengukur motivasi belajar mahasiswa. Skala yang disusun Utami dkk. (2014) ini didasarkan pada konstruk teori motivasi belajar menurut McCown dkk. (1996). Aspekaspek yang diungkap dalam skala motivasi belajar adalah keinginan atau inisiatif sendiri untuk belajar, keterlibatan secara sungguh-sungguh dalam proses belajar dan tugas yang diberikan, dan komitmen untuk terus belajar. Hasil analisis atas skala yang terdiri atas 18 aitem ini menunjukkan koefisien Cronbach $\alpha=0,903$.

Skala dukungan sosial, tepatnya MSPSS (the Multidimensional Scale of Perceived Social Support) adalah skala yang dimaksudkan untuk mengetahui dukungan sosial yang dimiliki subjek penelitian. Skala MSPSS yang disusun oleh Zimet et al. (1988) digunakan untuk mengukur variabel dukungan sosial, yang meliputi aspek-aspek dukungan teman, dukungan orang spesial, dan dukungan keluarga. Skala ini terdiri atas 12 aitem. Hasil analisis menunjukkan bahwa skala ini memiliki koefisien Cronbach's $\alpha=0.804$. 
Skala religiositas merupakan skala yang dimaksudkan untuk mengungkap tingkat religiositas subjek penelitian. Merujuk pada pendapat Ancok dan Suroso (2018), dimensi religiositas yang diungkap melalui skala religiositas: (1) yang meliputi akidah, ibadah, akhlak, dan ihsan dan skala religiositas; dan (2) yang berisi pengetahuan agama. Skala yang dirancang Nashori (2012) ini terdiri atas 32 aitem. Hasil analisis reliabilitas menunjukkan bahwa koefisien Cronbach $\alpha$ skala religiositas adalah 0.950 (excellenct) dan koefisien Cronbach $\alpha$ skala religiositas 2 adalah 0.870 (very good) (Azwar, 2015).

Teknik analisis data yang digunakan dalam penelitian ini adalah teknik analisis regresi bertahap. Teknik analisis ini digunakan untuk mengetahui apakah pengaruh dukungan sosial terhadap motivasi belajar melalui mediator religiositas terbukti secara empiris. Pada penelitian ini analisis data menggunakan perhitungan statistik dengan bantuan software Statistic Program for School Science (SPSS) versi 25.0 for Windows. Patokan nilai signifikansi yang digunakan adalah $\mathrm{p}<, 05$. Jika nilai $\mathrm{p}<, 05$ maka terdapat korelasi antara kedua variabel. Sebaliknya, apabila nilai $\mathrm{p}>, 05$ maka tidak terdapat korelasi antara kedua variabel. Selanjutnya, analisis mediasi yang dimaksudkan untuk mengecek signifikansi indirect effect akan menggunakan laman http://quantpsy.org/sobel/sobel.htm. Analisis di atas digunakan untuk mengetahui korelasi antara dukungan sosial dan motivasi belajar dengan religiositas sebagai mediator.

\section{PAPARAN HASIL}

Hasil penelitian ini memberi konfirmasi empiris atas hipotesis penelitian. Pertama: Hasil uji hipotesis 1, yaitu jalur a. Hasil penelitian menunjukkan bahwa dukungan sosial mempengaruhi religiositas. Hal ini dapat diketahui dari hasil analisis pada jalur a yang menghubungkan dukungan sosial dan religiositas (Tabel 1).

Tabel 1.

Coefficient Jalur a Pengaruh Dukungan sosial terhadap Religiositas

\begin{tabular}{|c|c|c|c|c|c|}
\hline \multirow[t]{2}{*}{ Model } & \multicolumn{2}{|c|}{$\begin{array}{c}\text { Unstandardized } \\
\text { Coefficients } \\
\end{array}$} & $\begin{array}{c}\text { Standardized } \\
\text { Coefficients }\end{array}$ & \multirow[t]{2}{*}{$\mathrm{T}$} & \multirow[t]{2}{*}{ Sig. } \\
\hline & B & Std. Error & Beta & & \\
\hline $\begin{array}{ll} & \text { (Constant }) \\
\text { dukungan sosial }\end{array}$ & $\begin{array}{l}-2,929 \\
, 051\end{array}$ & $\begin{array}{l}, 775 \\
, 013\end{array}$ & 261 & $\begin{array}{l}-3,781 \\
3,817\end{array}$ & $\begin{array}{l}000 \\
, 000\end{array}$ \\
\hline
\end{tabular}

Kedua: Hasil uji hipotesis 2, yaitu Jalur b. Hasil analisis juga menunjukkan bahwa religiositas mempengaruhi motivasi belajar. Hal ini dapat diketahui dari jalur b yang menghubungkan religiositas dan dan motivasi belajar (Tabel 2).

Tabel 2.

Coefficient Jalur b Pengaruh Religiositas terhadap Motivasi Belajar

\begin{tabular}{|c|c|c|c|c|c|c|}
\hline \multirow{2}{*}{\multicolumn{2}{|c|}{ Model }} & \multicolumn{2}{|c|}{$\begin{array}{c}\text { Unstandardized } \\
\text { Coefficient }\end{array}$} & \multirow{2}{*}{$\begin{array}{c}\text { Standardized } \\
\text { Coefficient }\end{array}$} & \multirow[t]{2}{*}{$\mathrm{T}$} & \multirow[t]{2}{*}{ Sig. } \\
\hline & & B & Std. Error & & & \\
\hline \multirow{2}{*}{1} & (Constant) & 48,520 & ,337 & & 144,163 & ,000 \\
\hline & religiusitas & 1,863 &, 213 &, 525 & 8,731 &, 000 \\
\hline
\end{tabular}


Ketiga: Hasil uji hipotesis 3, yaitu jalur c. Hasil analisis menunjukkan bahwa dukungan sosial tidak mempengaruhi mempengaruhi motivasi belajar ketia dilakukan kontrol terhadap religiusitas. Analisis awal yang dilakukan adalah menguji pengaruh dukungan sosial terhadap motivasi belajar. Hasilnya menunjukkan dukungan sosial mempengaruhi motivasi belajar. Hal ini dapat diketahui dari jalur c yang menghubungkan dukungan sosial dan motivasi belajar (Tabel 3).

Tabel 3.

Coefficient Jalur c Pengaruh Dukungan Sosial terhadap Motivasi Belajar

\begin{tabular}{|c|c|c|c|c|c|c|}
\hline \multirow{2}{*}{\multicolumn{2}{|c|}{ Model }} & \multicolumn{2}{|c|}{$\begin{array}{c}\text { Unstandardized } \\
\text { Coefficient }\end{array}$} & \multirow{2}{*}{$\begin{array}{c}\begin{array}{c}\text { Standardized } \\
\text { Coefficient }\end{array} \\
\text { Beta }\end{array}$} & \multirow[t]{2}{*}{$\mathrm{T}$} & \multirow[t]{2}{*}{ Sig. } \\
\hline & & B & Std. Error & & & \\
\hline \multirow{2}{*}{1} & (Constant) & 39,685 & 2,775 & & 14,299 & ,000 \\
\hline & dukungan sosial & 154 & ,048 & ,222 & 3,214 & ,002 \\
\hline
\end{tabular}

Ketika analisis dilakukan dengan mengontrol religiusitas, ternyata hasilnya berbeda. Hasil analisis menunjukkan bahwa dukungan sosial tidak mempengaruhi motivasi belajar setelah mengontrol religiusitas. Hasil ini menunjukkan bahwa direct effect pengaruh dukungan sosial terhadap motivasi belajar tidak signifikan (Tabel 4).

Tabel 4.

Coefficients Pengaruh Dukungan Sosial terhadap Motivasi Belajar dengan mengontrol Religiositas

\begin{tabular}{|c|c|c|c|c|c|c|}
\hline & \multirow[t]{2}{*}{ Model } & \multicolumn{2}{|c|}{$\begin{array}{c}\text { Unstandardized } \\
\text { Coefficient }\end{array}$} & \multirow{2}{*}{$\begin{array}{c}\begin{array}{c}\text { Standardized } \\
\text { Coefficient }\end{array} \\
\text { Beta }\end{array}$} & \multirow[t]{2}{*}{$\mathrm{T}$} & \multirow[t]{2}{*}{ Sig. } \\
\hline & & B & Std. Error & & & \\
\hline \multirow{3}{*}{1} & (Constant) & 44,896 & 2,500 & & 17,960 & 000 \\
\hline & dukungan sosial & ,063 & 043 & ,091 & 1,463 &, 145 \\
\hline & religiusitas & 1,779 & 220 & 502 & 8,072 & 000 \\
\hline
\end{tabular}

Keempat: Hasil uji hipotesis 5. Hasil analisis menunjukkan bahwa religiositas memediasi hubungan antara social support dan motivasi belajar. Hasil ini menunjukkan bahwa terdapat indirect effect pengaruh dukungan sosial terhadap motivasi belajar melalui religiositas bersifat signifikan (Gambar 1).

$$
\begin{aligned}
\text { Rumus indirect effect } & =\text { jalur } \mathrm{a} \times \text { jalur } \mathrm{b} \\
& =0,051 \times 1,863 \\
& =\mathbf{0 , 0 9 5} \rightarrow \text { besarnya indirect effect. }
\end{aligned}
$$

Untuk mengetahui signfikansinya, dilakukan uji sobel. Hasil analisis uji sobel menunjukkan bahwa $\mathrm{p}$ (2-tailed) sebesar 0,000, yang artinya pengaruh dukungan sosial terhadap motivasi belajar melalui religiositas bersifat signifikan. 
Raden Rachmy Diana, dkk | Motivasi Belajar Mahasiswa

\begin{tabular}{|c|c|c|c|c|c|}
\hline & Input: & & Test statistic: & Std. Error: & $p$-value: \\
\hline$a$ & 0.051 & Sobel test: & 3.57950177 & 0.02654364 & 0.00034425 \\
\hline$b$ & 1.863 & Aroian test: & 3.56018251 & 0.02668768 & 0.0003706 \\
\hline$s_{a}$ & 0.013 & Goodman test: & 3.59913899 & 0.02639881 & 0.00031927 \\
\hline & 0.213 & Reset all & \multicolumn{3}{|c|}{ Calculate } \\
\hline
\end{tabular}

Gambar 1. Hasil uji sobel (N=202)

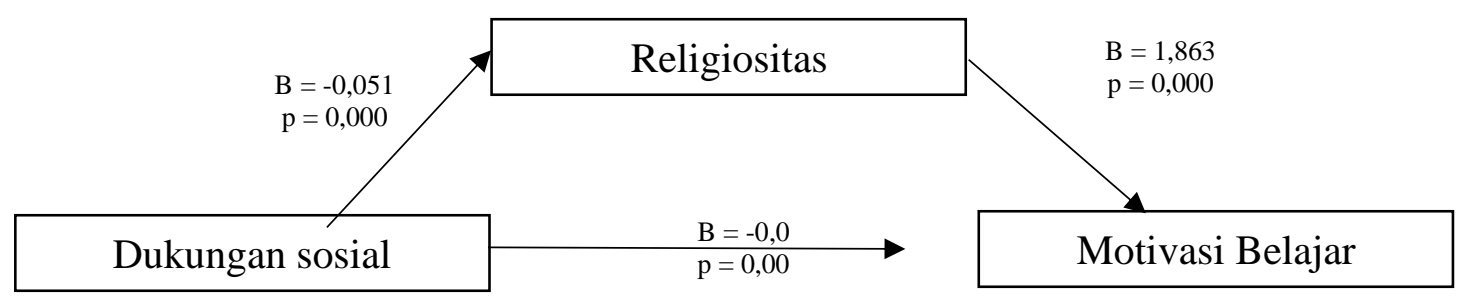

Merujuk pada pendapat Baron dan Kenny (1986), apabila direct effect tidak signifikan sedangkan indirect effect signifikan, maka terjadilah mediasi sempurna. Dengan demikian, pengaruh dukungan sosial terhadap motivasi belajar dimediasi secara sempurna oleh religiositas.

\section{PEMBAHASAN}

Tujuan utama dari penelitian ini adalah untuk mengetahui pengaruh dukungan sosial yang dirasakan (dari keluarga, teman, dan orang-orang khusus) terhadap motivasi belajar mahasiswa dengan mediator religiositas. Temuan penelitian ini menunjukkan bahwa pengaruh dukungan sosial terhadap motivasi belajar mahasiswa dimediasi secara sempurna oleh religiositas.

Hasil analisis ini mengoreksi hasil-hasil penelitian sebelumnya yang menunjukkan bahwa ada korelasi positif secara langsung antara dukungan yang diberikan oleh keluarga, teman, dan orang-orang khusus dan motivasi belajar mahasiswa. Hasil penelitian sebelumnya (Akinsanya et al., 2011; Atnafu, 2012; Gottfried, Fleming, \& Gottfried, 1994; Kim, 2016) menunjukkan bahwa dukungan, penghargaan, dan pujian yang diterima individu dari orang tua dan kalangan dalam khususnya, meningkatkan tingkat motivasi akademik mahasiswa. Dukungan sosial yang dirasakan dari keluarga, teman, orang-orang khusus yang diterima oleh mahasiswa, berkaitan dengan dan berkontribusi kepada motivasi belajar mahasiswa (Chen, 2015; Mata et al., 2012). Penelitian lainnya (Abdullah \& Al-Mofti, 2017; DeFreese \& Smith, 2013; Legault et al., 2006; Paul et al., 2015; Putri, 2018; Sambada, 2017; Sholihah, 2015; Vatankhah \& Tanbakooei, 2014; Zulkarnain, Sari, \& Purwadi, 2019) juga membuktikan bahwa adanya korelasi positif antara dukungan sosial (dari orang tua, guru dan teman sebaya) dan motivasi belajar mahasiswa. Semakin tinggi dukungan sosialnya, semakin tinggi juga motivasi belajar mahasiswa, bahkan dalam penelitian Permatasari (2018), dukungan sosial orang tua secara langsung 
berkontribusi sebesar $53,4 \%$ terhadap motivasi belajar mahasiswa program studi psikologi.

Hasil penelitian ini menunjukkan secara jelas bahwa agar dukungan sosial memberi efek yang signifikan terhadap motivasi belajar dibutuhkan adanya religiositas. Dikatakan oleh Najati (2015) bahwa motivasi belajar yang kuat itu dapat muncul karena religiositas yang dimiliki individu termasuk besar. Ketika individu memahami dan menghayati isi ajaran agama Islam, maka individu tahu bahwa agama mendorong individu untuk memiliki kesungguhan dalam belajar. Sedemikian pentingnya belajar, hingga perintah pertama Allah subhanahu wa ta'ala (swt) kepada Nabi Muhammad shollalohu 'alaihi wassalam (saw) adalah iqra', yang intinya adalah pentingnya untuk belajar. Selain itu, agama mendorong setiap pemeluknya untuk terus menerus belajar, bahkan belajar sepanjang hayatnya.

Dikatakan oleh Deci (1971) dan Deci and Ryan (1994) bahwa unsur-unsur motivasi yang berasal dari stimulus eksternal memiliki potensi untuk diinternalisasi. Hasil penelitian ini menunjukkan bahwa religiositas dapat mengantarkan individu menginternalisasi dukungan sosial yang berasal dari orang lain. Dukungan sosial dari orangtua, dosen, dan teman yang dirasakan oleh mahasiswa dapat mendorong mahasiswa untuk mengambil tanggung jawab pada tugas dan kegiatan belajar dan untuk mencapai keberhasilan dengan tugas tersebut.

Religiositas dalam diri individu dapat berperan sebagai pemberi makna atas dukungan sosial yang diberikan. Dukungan orangtua untuk menjalani kegiatan pembelajaran dengan baik diberi makna oleh individu sebagai bentuk tindakan berbakti kepada orangtua. Dukungan yang diberikan oleh dosen diberi makna oleh subjek penelitian sebagai bentuk kepatuhan yang dapat menghadirkan berkah bagi mahasiswa.

Dinamikanya bahwa religiositas diperlukan dalam mengintegrasikan dukungan sosial terhadap motivasi belajar adalah konsep tauhid yang mendasari keimanan. Konsep tauhid yang dimaksud adalah tujuan penciptaan manusia tidak ada yang lain kecuali beribadah kepada Allah swt karena tidak ada tuhan yang berhak untuk disembah kecuali Allah swt. Konsep tauhid ini dalam struktur keimanan menempati urutan nomor satu, yaitu syahadat atau kesaksian atas ke-esa-an Allah swt. Allah swt menegaskan bahwa hanya dengan ilmu mendalam seorang mukmin mampu bersaksi dengan baik terhadap makna tidak ada tuhan selain Allah swt (QS. 3: 18).

Hal ini didukung hasil penelitian Soeprayitno dan Rahayu (2019) bahwa motivasi dibentuk atau dipengaruhi secara signifikan oleh manajemen pengetahuan khususnya pengetahuan agama Islam. Manajemen pengetahuan Islam yang komprehensif berpotensi membawa pada pemahaman makna tauhid. Muhaya (2015) mengutip Al-Ghazali menyebut bahwa pengetahuan atau ilmu dalam Islam harus disatukan dalam kesatuan seperti tiga sudut pada segitiga: (1) secara ontologis ilmu berasal dari Allah dan tidak dapat dipisahkan dari Allah swt; (2) Secara epistimologis ilmu dapat diperoleh dengan mengoptimalkan fungsi akal dan wahyu; (3) Secara axiologi, ilmu daperuntukkan bagi 
kesejahteraan alam semesta, termasuk manusia dengan niat pengabdian kepada Allah swt. Barus (2016) menyebut bahwa tauhid adalah inti yang mendasari setiap aktivitas muslim, baik sosial, budaya, ekonomi, ataupun politik. Secara operasional berarti memahami dan merasakan kedekatan, diperhatikan, terus diawasi dengan kasih sayang oleh Allah swt.

Religiositas menjadi mediator yang sempurna turut dipengaruhi oleh perkembangan subjek penelitian, di mana dalam penelitian ini subjek penelitian adalah mahasiswa. Mahasiswa merupakan individu yang berada dapat tahap perkembangan dewasa awal. Menurut Jalaluddin (2016), masa dewasa membuat seseorang memikirkan lebih banyak hal daripada masa remaja dan anak-anak, termasuk memikirkan religiositas. Mahasiswa yang telah mencapai usia dewasa telah mencapai perkembangan religiositas yang cukup matang, bukan sekedar ikut-ikutan, karena mereka sudah memiliki pemikiran pascaformal (Papalia, Olds, \& Feldman, 2007). Pemikiran pascaformal ini membuat seorang dewasa mampu berpikir mandiri. Tidak seperti anak-anak dan remaja yang tahapan berpikirnya belum matang, sehingga belum memiliki prinsip yang membuatnya beragama dengan cara imitasi saja.

Mahasiswa yang berada pada usia dewasa juga mulai bersikap positif terhadap ajaran agama, disebabkan oleh sudah berkembangnya moral dalam dirinya (Papalia et al., 2007), religiositas didasarkan atas tanggung jawab (Schaie \& Willis, 2000), cenderung bersikap idealis, memiliki dorongan internal untuk beragama dan sudah memiliki kemampuan untuk memahami, mengimplementasikan, dan mengamalkan ajaran agama secara penuh (Saifuddin, 2019).

\section{SIMPULAN}

Hasil penelitian menunjukkan bahwa dukungan sosial memberikan pengaruh terhadap motivasi belajar dengan religiositas sebagai mediator secara penuh. Artinya penelitian ini menunjukkan secara jelas bahwa agar dukungan sosial memberi efek yang signifikan terhadap motivasi belajar dibutuhkan adanya religiositas. Selain itu, hasil penelitian juga menunjukkan bahwa dukungan sosial berpengaruh terhadap religiusitas, religiusitas berpengaruh terhadap motivasi belajar, dan dukungan sosial tidak mempengaruhi motivasi belajar.

\section{SARAN DAN REKOMENDASI}

Saran peneliti untuk para mahasiswa, guna meningkatkan motivasi belajar, penting bagi mahasiswa untuk memiliki nilai religiositas yang tinggi dengan cara meningkatkan keimanan dan ketakwaan, melalui menjalankan ritual-ritual keagamaan, baik ibadah wajib maupun sunnah, serta mengikuti kajian Islam serta mengikuti kegiatankegiatan yang bernilai positif.

Bagi orang tua, penting untuk memberikan dukungan sosial berbasis religiositas, dengan cara menanamkan nilai-nilai religiositas kepada anak sejak dini dengan cara yang menyenangkan dan penuh kelekatan, sehingga religiositas hadir pada diri individu tidak 
sekedar sebagai doktrin, tapi sebagai sebuah kebutuhan pokok yang akrab dengan kehidupannya.

Bagi lembaga pendidikan (universitas) penting untuk mempertimbangkan aspek religiositas terkait pembinaan kepada mahasiswa, salah satunya dengan mengadakan pelatihan-pelatihan berbasis religiositas. Secara praktis perlu dipertimbangkan untuk menghidupkan suasana yang penuh dukungan sosial dengan basis religiositas untuk dapat meningkatkan motivasi belajar mahasiswa.

Saran peneliti untuk penelitian selanjutnya adalah bahwa perlu penelitian lanjutan dengan sampel dari usia yang berbeda. Variabel usia juga perlu dijadikan pertimbangan, mengingat perkembangan religiositas antar usia berbeda-beda, dan tidak dapat dipungkiri bahwa dalam sebuah populasi mahasiswa bisa terdapat dua macam usia, yaitu remaja atau dewasa awal, sehingga penting untuk mengelompokkan mahasiswa tersebut berdasarkan jenjang usia remaja atau dewasa awal. Mengingat pentingnya peran religiositas sebagais variabel mediator, penting untuk melakukan penelitian-penelitian serupa, mengingat masih sedikit penelitian yang menjadikan religiositas sebagai variabel mediator, dan bagi penelitian mendatang dapat menambah variabel-variabel lain, selain variabel yang digunakan saat ini, seperti konsep diri akademik, resiliensi akademik, prokrastinasi akademik, efikasi diri akademik, dan sebagainya. Bisa juga menambahkan variabel moderasi maupun perpaduan antara moderasi dan mediasi.

Subjek dalam penelitian ini juga masih terbatas, karena jumlah dan lingkup area di sebuah universitas islam, sehingga relatif belum bisa digeneralisasi untuk populasi yang lebih luas. Penelitian mendatang dapat menggunakan sampel secara lebih luas agar diperoleh hasil penelitian yang lebih baik dan lebih bisa digeneralisasi.

Saran untuk peneliti selanjutnya untuk dapat mempertimbangkan spesifikasi motivasi belajar yang akan diteliti, seperti motivasi belajar pada mata pelajaran matematika, atau motivasi belajar pada mata kuliah statistik. Penting juga untuk membedakan mahasiswa berdasarkan kelompok aktitivitas, seperti mahasiswa yang berstatus sebagai santri di pondok pesantren mahasiswa ataupun rumah tahfidz, mahasiswa yang aktif dalam kegiatan UKM Kerohanian, mahasiswa yang aktif dalam pecinta alam, badan eksekutif mahasiswa, dan lain sebagainya. 


\section{DAFTAR PUSTAKA}

Abdullah, M. Y., \& Al-Mofti, K. W. H. (2017). The Impact of Social Support on EFL Learners' Motivation at Iraqi Kurdistan Universities. Modern Applied Science, 11(7), 51. https://doi.org/10.5539/mas.v11n7p51

Akidah, I., \& Mansyur, U. (2019). Pengaruh Motivasi Belajar Terhadap Keterampilan Menulis Berita Mahasiswa. Jurnal Ilmiah Kependidikan, XIII, 71-78.

Akinsanya, O. O., Ajayi, K. O., \& Salomi, M. O. (2011). Relative Effects of Parents' Occupation, Qualification and Academic Motivation of Wards on Students' Achievement in Senior Secondary School Mathematics in Ogun State. British Journal of Arts and Social Sciences, 3(2), 2046-9578. http://www.bjournal.co.uk/ BJASS.aspx

Ancok, D., \& Suroso, F. N. (2018). Psikologi Islami (Islamic psychology). Nucleic Acids Research. Pustaka Belajar.

Anita, I. W. A. W. (2015). Pengaruh Motivasi Belajar Ditinjau Dari Jenis Kelamin Terhadap Kemampuan Berpikir Kritis Matematis. P2M STKIP Siliwangi, 2(2), 246. https://doi.org/10.22460/p2m.v2i2p246-251.184

Atnafu, M. (2012). Motivation, Social Support, Alienation from the School and their Impact on Students' Achievement in Mathematics: The Case of Tenth Grade Students. Ethiopian Journal of Education and Sciences, 8(1), 53-74.

Azwar, S. (2015). Realibilitas dan Validitas. Pustaka Belajar.

Baron, R. M., \& Kenny, D. A. (1986). The Moderator-Mediator Variable Distinction in Social Psychological Research. Conceptual, Strategic, and Statistical Considerations. Journal of Personality and Social Psychology, 51(6), 1173-1182. https://doi.org/10.1037/0022-3514.51.6.1173

Barrett, D. W., Patock-Peckham, J. A., Hutchinson, G. T., \& Nagoshi, C. T. (2005). Cognitive motivation and religious orientation. Personality and Individual Differences, 38(2), 461-474. https://doi.org/10.1016/j.paid.2004.05.004

Barus, E. E. (2016). Tauhid Sebagai Fundamental Filsafah Ekonomi Islam. Jurnal Perspektif Ekonomi Darussalam, 2(1), 69-79. https://doi.org/10.24815/ jped.v2i1.6648

Chen, W. W. (2015). The relations between perceived parenting styles and academic achievement in Hong Kong: The mediating role of students' goal orientations. Learning and Individual Differences, 37, 48-54. https://doi.org/10.1016/ j.lindif.2014.11.021

Deci, E. L. (1971). Effects of externally mediated rewards on intrinsic motivation. Journal of Personality and Social Psychology, 18(1), 105-115. https://doi.org/ $10.1037 / \mathrm{h} 0030644$

Deci, E. L., \& Ryan, R. M. (1994). Promoting Self-determined Education. Scandinavian Journal of Educational Research, 38(1), 3-14. https://doi.org/10.1080/ 


\section{1}

DeFreese, J. D., \& Smith, A. L. (2013). Teammate social support, burnout, and selfdetermined motivation in collegiate athletes. Psychology of Sport and Exercise, 14(2), 258-265. https://doi.org/10.1016/j.psychsport.2012.10.009

Dunn, T. J., \& Kennedy, M. (2019). Technology Enhanced Learning in higher education; motivations, engagement and academic achievement. Computers and Education, 137(March), 104-113. https://doi.org/10.1016/j.compedu.2019.04.004

Emeralda, G. N., \& Kristiana, I. F. (2017). Hubungan Antara Dukungan Sosial Orang Tua Sekolah Menengah Pertama. Empati, 7(3), 154-159.

Fatima, S., Mehfooz, M., \& Sharif, S. (2017). Role of Islamic Religiosity in Predicting Academic Motivation of University Students. Psychology of Religion and Spirituality, 9, 377_386. https://doi.org/https://doi.org/10.1037/rel0000097

Filak, V. F., \& Sheldon, K. M. (2008). Teacher support, student motivation, student need satisfaction, and college teacher course evaluations: Testing a sequential path model. Educational Psychology, 28(6), 711-724. https://doi.org/10.1080/ 01443410802337794

Gottfried, A. E., Fleming, J. S., \& Gottfried, A. W. (1994). Role of Parental Motivational Practices in Children's Academic Intrinsic Motivation and Achievement. Journal of Educational Psychology, 86(1), 104-113. https://doi.org/10.1037/00220663.86.1.104

Jalaluddin. (2016). Psikologi Agama: Memahami Perilaku dengan Mengaplikasikan Prinsip-Prinsip Psikologi (Edisi Revisi 2016). Raja Grafindo Persada.

Kim, E. (2016). The Relationship Between Parental Involvement and Children's Educational Achievement in the Korean Immigrant Family Author(s): EUNJUNG KIM. Journal of Comparative Family Studies, 33(4), 529-540.

Kurnianingtyas, D. (2015). Pengaruh Religiusitas, Perhatian Orangtua, dan Motivasi Belajar terhadap Prestasi Akademik Mahasiswa Prodi Pendidikan Agama Islam Angkatan 2012/2013 Universitas Muhammadiyah Yogyakarta. Fakultas Agama Islam Universitas Muhammadiyah Yogyakarta. Universitas Muhammadiyah Yogyakarta. http://repository.umy.ac.id/handle/123456789/18100

Law, K. M. Y., Geng, S., \& Li, T. (2019). Student enrollment, motivation and learning performance in a blended learning environment: The mediating effects of social, teaching, and cognitive presence. Computers and Education, 136(March), 1-12. https://doi.org/10.1016/j.compedu.2019.02.021

Legault, L., Green-Demers, I., \& Pelletier, L. (2006). Why do high school students lack motivation in the classroom? Toward an understanding of academic amotivation and the role of social support. Journal of Educational Psychology, 98(3), 567582. https://doi.org/10.1037/0022-0663.98.3.567

Manurung, T. M. S. (2017). Pengaruh Motivasi dan Perilaku Belajar Terhadap Prestasi 
Akademik Mahasiswa. JAS-PT Jurnal Analisis Sistem Pendidikan Tinggi, 1(1), 17. https://doi.org/10.36339/jaspt.v1i1.36

Mata, M. de L., Monteiro, V., \& Peixoto, F. (2012). Attitudes towards Mathematics: Effects of Individual, Motivational, and Social Support Factors. Child Development Research, 2012, 1-10. https://doi.org/10.1155/2012/876028

McCown, R., Driscoll, M., \& Roop, P. G. (1996). Educational psychology: A learningcentered approach to classroom practice. Annual review of psychology. Allyn \& Bacon. https://doi.org/10.1146/annurev.ps.13.020162.002103

Muhaya, A. (2015). Unity of Sciences According To Al-Ghazali. Walisongo: Jurnal Penelitian Sosial Keagamaan, 23(2), 311. https://doi.org/10.21580/ws.23.2.281

Mustafidah, H. (2010). Model Regresi Data Mining Motivasi Belajar Pengaruhnya Terhadap Tingkat Kedisiplinan Mahasiswa (Data Mining Regression Models of Learning Motivation Effect on Disciplinary Level of Students). JUITA Universitas Muhammadiyah Purwokerto, I(1), 1-4.

Najati, M. U. (2015). Al-Quran dan Ilmu Jiwa. Pustaka Hidayah.

Nashori, F. (2012). Pemaafan pada Etnis Jawa: Studi model pengaruh religiositas dan keterikatan interpersonal terhadap pemaafan pada etnis Jawa melalui sifat kebersetujuan dan sifat neurotisisme (kasus warga Kota Yogyakarta). Disertasi. Universitas Padjadjaran, Bandung.

Novitarum, L., Tampubolon, L. F., \& Manurung, R. A. (2018). Hubungan Motivasi Belajar Dengan Kecemasan Mahasiswa Menghadapi Osce. Jurnal Mutiara Ners, 1(1), 11-18.

Oh, H. (2017). Influence of learning motivation, communication skill, academic selfefficacy on self-directed learning ability in nursing student, 15(8), 311-321. https://doi.org/doi.org/10.14400/JDC.2017.15.8.311

Paninten, G.A. \& Indrawati, E.S. (2020). Hubungan antara dukungan sosial teman sebaya dengan religiusitas pada komunitas Cah Hijrah Semarang. Jurnal EMPATI, 9 (4), 262-279.

Papalia, Olds, \& Feldman. (2007). Human Development: 10 Edition. McGraw-Hill Education (Asia).

Paul, H., Subalukshmi, S. S. S., \& Mala, V. (2015). Resilience, academic motivation and social support among college students. Indian Journal of Positive Psychology, 6(1), 106-110. https://login.ezproxy.net.ucf.edu/login?auth=shibb\&url= http://search.ebscohost.com/login.aspx?direct=true\&db=edb\&AN=100812569\&s ite $=$ eds-live \&scope $=$ site

Permana, A. D. I. (2016). Pengaruh Gaya Belajar Dan Motivasi Belajar Mahasiswa Terhadap Kemampuan Belajar Ilmu Alamiah Dasar, Jurnal Formatif, 6(3), 276283.

Permatasari, D. S. (2018). Hubungan antara Dukungan Sosial Orangtua dengan Motivasi 
Belajar pada Mahasiswa Program Studi Psikologi Universitas Mercu Buana Yogyakarta. Universitas Mercu Buana Yogyakarta.

Putri, N. N. S. (2018). Hubungan Dukungan Sosial terhadap Motivasi Belajar pada Mahasiswa Perantau Universitas Katolik Soegijapranata Semarang. Fakultas Psikologi Universitas Katolik Soegijapranata. Universitas Katolik Soegijapranata. http://repository.unika.ac.id/id/eprint/19138

Rasdjo. D.S, Hendrayana, A. S., Erisyani, E., \& Setiana, N. (2016). Kemandirian Belajar Terhadap Hasil Belajar Mahasiswa S1 PGSD Masukan Sarjana Di UPBJJ UT. Bandung. Jurnal Pendidikan Dasar, 8(2), 154-167.

Rettinger, D. A., \& Jordan, A. E. (2005). The relations among religion, motivation, and college cheating: A natural experiment. Ethics and Behavior, 15(2), 107-129. https://doi.org/10.1207/s15327019eb1502_2

Saifuddin, A. (2019). Psikologi Agama, Implementasi Psikologi untuk Memahami Perilaku Beragama. Kencana.

Sakiz, G. (2012). Perceived instructor affective support in relation to academic emotions and motivation in college. Educational Psychology, 32(1), 63-79. https://doi.org/ 10.1080/01443410.2011.625611

Sambada, M. A. A. (2017). Hubungan antara Dukungan Sosial Orang Tua dengan Motivasi Belajar pada Mahasiswa Atlet. Empati. Universitas Brawijaya. http://repository.ub.ac.id/id/eprint/420

Sappaile, B. I., \& Pristiwaluyo, T. (2019). Pengaruh Motivasi Belajar Dan Konsep Diri Terhadap Kemampuan Pemecahan Masalah Matematika. Indonesian Journal of Educational Studies, 22(1), 1-7. https://doi.org/10.26858/ijes.v22i1.9341

Sarafino, E. P., \& Smith, T. W. (2012). Health psychology: Biopsychosocial interactions. New Jersey: John Wiley and Sons. https://doi.org/10.1037/10113-006

Schaie, K. W., \& Willis, S. L. (2000). A stage theory model of adult cognitive development revisited. Springer Publishing Company, 8(2), 129-138. https://doi.org/10.2190/1TEA-M6PK-28A0-49HV

Sholihah, S. (2015). Pengaruh Dukungan Sosial Terhadap Peningkatan Motivasi Belajar Mahasiswa Pgsd Ums Angkatan 2012/2013. Universitas Muhammadiyah Surakarta. http://eprints.ums.ac.id/id/eprint/32646

Soeprayitno, S., \& Rahayu, P. Y. (2019). The Influence of Knowledge Management towards Motivation Teaching in Boarding Schools. International Journal of Active Learning, 4(2), 114-125. https://journal.unnes.ac.id/nju/index.php/ijal/article/ view/18109

Suciana, D., \& Rozali, Y. A. (2014). Hubungan Dukungan Sosial dengan Motivasi Belajar pada Mahasiswa Universitas Esa Unggul. Jurnal Psikologi, 12(2), 43-47.

Sun, Y., \& Gao, F. (2020). An investigation of the influence of intrinsic motivation on students' intention to use mobile devices in language learning. Educational 
Technology Research and Development, 68(3), 1181-1198. https://doi.org/ 10.1007/s11423-019-09733-9

Susilawati, S. (2018). Perbedaan Religiusitas Dan Motivasi Berprestasi Pada Mahasiswa Universitas Islam Negeri Uin Maulana Malik Ibrahim Malang. JPIPS: Jurnal Pendidikan Ilmu Pengetahuan Sosial, 5(1), 14-26. http://ejournal.uinmalang.ac.id/index.php/jpips

Syauqi, T. A. (2019). Gambaran Motivasi Berprestasi Peer Group Religius Pada Mahasiswa. Psikis: Jurnal Psikologi Islami, 5(2), 133-139. https://doi.org/ 10.19109/psikis.v5i2.2936

Trisno, A. (2010). Perbedaan Motivasi Berprestasi Antara Mahasiswa Aktivis Dan Non Aktivis Ukm Kerohanian Di Universitas Merdeka Malang. Jurnal Psikologi Tabularasa, 5(2), 323-334.

Utami, L. H., \& Nurjati, L. N. (2017). Hubungan Self-Efficacy, Belief Dan Motivasi Dengan Kecemasan Mahasiswa Dalam Pembelajaran Bahasa Inggris. Psympathic, Jurnal Ilmiah Psikologi, 4(2), 219-238.

Utami, S., Nashori, H. F., \& Rachmawati, M. A. (2014). Pengaruh pelatihan adversity quotient untuk meningkatkan motivasi belajar siswa sekolah menengah pertama effect of adversity quotient training to improve learning motivation among junior high school students. Jurnal Intervensi Psikologi, 6(1), 131-149.

Vatankhah, M., \& Tanbakooei, N. (2014). The Role of Social Support on Intrinsic and Extrinsic Motivation among Iranian EFL Learners. Procedia - Social and Behavioral Sciences, 98, 1912-1918. https://doi.org/10.1016/j.sbspro.2014.03.622

Wiyoko, T., \& Setiawan, I. (2019). Penerapan Edmodo untuk Meningkatkan Motivasi Belajar Mahasiswa PGSD STKIP Muhammadiyah Muara Bungo. Jurnal Muara Pendidikan, 4(1), 238-245.

Zanthy, L. S. (2016). Pengaruh Motivasi Belajar Ditinjau Dari Latar Belakang Pilihan Jurusan Terhadap Kemampuan Berpikir Kritis Mahasiswa Di STKIP Siliwangi Bandung. Teorema, 1(1), 47. https://doi.org/10.25157/.v1i1.540

Zimet, G. D., Dahlem, N. W., Zimet, S. G., \& Farley, G. K. (1988). The Multidimensional Scale of Perceived Social Support. Journal of Personality Assessment, 52(1), 3041. https://doi.org/10.1207/s15327752jpa5201_2

Zulkarnain, M., Sari, E. Y. D., \& Purwadi. (2019). Peranan dukungan sosial dan self esteem dalam meningkatkan motivasi belajar. Prosiding Seminar Nasional Magister Psikologi Universitas Ahmad Dahlan, 447-453. 